\title{
Optimization of Stock Portfolio Using the Markowitz Model in the Era of the COVID-19 Pandemic
}

\author{
Aisha Hanif a ${ }^{1}$ D , Nur Ravita Hanun a ${ }^{\text {iD }}$, Rizki Eka Febriansah a iD \\ ${ }^{a}$ Universitas Muhammadiyah Sidoarjo, Indonesia
}

\begin{abstract}
APA Citation:
Hanif, A., Hanun, N. R. \& Febriansah, R. E. (2021). Optimization of the stock portfolio using the Markowitz model in the era of the covid-19 pandemic. TIJAB (The International Journal of Applied Business), 5(1), 37-50.

Submission Date: 03/02/2021

Acceptance Date: 16/04/2021
\end{abstract}

\begin{abstract}
Stocks are one of the popular investment instruments traded in the capital market. The popularity of stock purchase has developed along with the massive financial literacy movement. However, the massiveness of this movement must be balanced with knowledge and expertise in managing stock instruments since they have a high return rate and high risk. One way to manage stocks is by developing an optimal stock portfolio based on the Markowitz model. The Markowitz model is a method that formulates the elements of return and risk in an investment, and specifically the elements of risk can be minimized through diversification and combination of various investment instruments into a portfolio. By using the Markowitz method, investors can take advantage of all available information as a basis for maximizing the portfolio. This study aimed to determine which stocks can form an optimal portfolio, especially in the era of the COVID 19 pandemic and the optimal proportion of the portfolio that is feasible to obtain from stocks listed in the LQ 45 Index. The study samples involved stocks listed in the LQ 45 Index. The data analysis technique applied in this study was portfolio optimization using the Markowitz model. The results of this study showed that the optimal portfolio consisted of BBCA with a weight of 78.09\% and BRPT with a weight of $21.91 \%$ which produced an expected return of $2.35 \%$ and a standard deviation of $7.01 \%$.
\end{abstract}

Keywords: optimization; portfolio; stock; Markowitz model

\section{Introduction}

An expert explains that investment will bring an outcome or return, which motivates investors to invest and rewards them to have courage in facing the future risks. Investments can be made for various types of assets, namely real assets and financial assets. Investment in financial assets is more liquid or does not take a long time for return. The liquidity exists as the fluctuation in the value of financial assets

\footnotetext{
${ }^{1}$ Corresponding author.

E-mail address: aishahanif@umsida.ac.id
} 
is quite significant. In a short period, the value of the assets can change and thus encourage investors to invest (Tandelilin, 2010).

Financial assets are a wide range of assets claimed by the issuer of the security. Financial assets are preferred because they are more liquid (easier to cash out) and diversifiable. The assets offer a higher return rate than real assets. Investors expect that money they invest will yield a high return while posing a little risk. Concerning about financial instrument, stocks can be exchanged on the stock exchange. In comparison to the money market, which includes savings and deposits, stocks are the most common investment instrument in the capital market (Zalmi, 2011). Based on the various types of stocks, the Indonesia Stock Exchange has grouped stocks by issuing multiple stock indexes consisting of companies with different parameters as references such as the JIC, Sectoral Index, LQ45, Jakarta Islamic Index ( JII), KOMPAS100, and others. The references will guide investors to easier decision-making.

The LQ45 index is preferred a lot because it contains a large number of stocks with high liquidity (Wiryakusuma, 2020). It is formed of 45 IDX stocks with high liquidity and high market capitalization. When it comes to identifying the market volatility of actively traded stocks, fund managers, financial analysts, capital market observers depend on the LQ45 index. The stock exchange controls the growth of the fourty-five stocks in the index regularly. Shares in the index are replaced every six months at the beginning of February and August. If stocks do not suit the allocation criteria, they will be removed from the index calculation and replaced with other shares. Investors must be selective when deciding the stocks listed to invest in and the feasibility of the shares (Putra \& Dana, 2020).

In investment, an investor does not certainly know the return. Moreover, they must be ready to face the future investment risk (Samsul, 2015). To minimize the risk, they can diversify the invesments by forming an optimal portfolio. A portfolio is deemed efficient compared to other portfolios since it gives the largest expected return with the same risk or provides the smallest risk with the same expected return (Halim, 2015). In 1952, Markowitz developed a portfolio selection model that incorporates the principle of diversification. The determination of the optimal portfolio is known as the Markowitz model (Elton et al., 2014). Optimal portfolios with the Markowitz model, which are selected from various alternative efficient portfolios, can provide certain returns according to the risks that investors expect (Ticoh, 2010). The Markowitz Model functions to form a portfolio easily that is suitable with the investment characteristics and desired goals (Natalia et al. 2012).

Aside from the immediate tragedies of death and illness, indirect consequences such as anxiety are gripping a large number of people and investors around the world, wreaking havoc on the global financial markets (Qing, Junyi, Sizhu, \& Jishuang, 2020). On the other hand, it cannot be denied that there are various unexpected risks in investment due to some disasters such as the Covid-19 pandemic. The infection of COVID-19 throughout the world, especially Indonesia, has had a profound impact on the economy including stock investment. On May 18, 2020, the Jakarta Stock Composite Index (JKSE) price was Rp 4,511, a decrease of around -28.21\% (Year to Date/ YTD) from January 2, 2020, Rp 6,284. The Covid-19 pandemic has also caused the Rupiah's exchange rate to depreciate against the US Dollar (USD). In the same time frame, the Rupiah's exchange rate to the US dollar fell by about $6.65 \%$ (YTD). Dewi and Masithoh (2020) stated that the IHSG index has experienced a significant difference which is a sharp downward trend during the COVID-19 pandemic. By looking at the previous issues, this study aimed to determine the optimization of stock portfolios using the Markowitz model in the era of the COVID-19 pandemic. It is important to conduct as investors may gain insights about how to choose and select stocks to be formed as portfolios to gain profits as expected to be balanced with the risks undertaken. 


\section{Literature Review}

Stock investment is expected to generate financial returns in the future through investment of some funds at the current time (Pratama et al, 2020). Therefore, data and information are important analysis factors for an investor to decide a type of investment. Based on the data and information analyses, a model for decision-making on stock investment will be developed. It will cover investment appraisal criteria that allow investors to choose the best investment from the available alternatives.

\subsection{Portfolio Theory}

A portfolio is a combination of some assets that are invested and owned by individuals and groups (Sunariyah, 2006). According to Sunariyah (2006), a portfolio may belong to an individual or an institution. Meanwhile, according to Husnan (2009), a portfolio is a collection of investments to identify the selected stocks and determine the proportion of funds for investment in each stock. Asset diversification can be done to develop a portfolio and reduce risks. Diversification means that investors will form portfolios by choosing a combination of various assets to minimize risks without reducing expected returns in accordance with the investment goal of investors (Tandelilin, 2010).

Gurrib and Alshahrani (2012) conducted a study on portfolio diversification and found that it could help reduce the associated risks. However, they argued that it was impossible to get rid of risk entirely through diversification. Tandelilin (2010) argued that the concept of risk reduction as a result of "adding assets to a portfolio" is mainly to understand portfolio risks. This concept explains that if other stocks are added continuously into a portfolio, the benefits of risk reduction will increase until it reaches a point where the benefits of the reduction start to decrease. An optimal portfolio must be efficient portfolios, but not vice versa (Hartono, 2014). Furthermore, Tandelilin (2010) defined an optimal portfolio is the most profitable for an investor since it has been screened from various portfolios.

\subsection{Markowitz Theory}

Outcome expected by investors from the investment is often called a return. Besides return, investment also has a risk which can be interpreted as the difference between actual return and expected return. Risk and return are similar to currencies that always go side by side. Investors should not only calculate the expected return but also pay attention to the risks to be taken. Therefore, investors must be smart to look for alternative investments that offer a certain return at the lowest risk level (Tandelilin, 2010).

Tandelilin (2010) also stated that investors have a goal to maximize return rates without forgetting the level of investment risk taken. Return is a motivation to invest and is a reward for encouraging investors to take the level of risk. According to Tandelilin (2010), portfolio risk is not a risk-weighted average of each security in a portfolio. In calculating portfolio risk, investors need to consider three things which are the variance of each security, the covariance between one security and another, and the portfolio weight for each security. According to Tandelilin (2010), risk diversification is an important step for investors because it can minimize the level of risk without reducing the return. The Markowitz model can help investors find out all the information available as a basis for forming an optimal portfolio. 


\subsection{Stock Investments}

Stock is known as an individual's, group's, or institution's ownership (Darmadji \& Fakhruddin, 2012). The amount of stocks owned by a person or an entity determines the percentage of company ownership. Stockholders have the right to vote numerous significant economic decisions. Furthermore, they have the right to claim the company's earnings as well as its assets (Tandelilin, 2010). As compared to savings and government securities as in a deposit, stocks are the most common investment instrument throughout the capital market. Stocks have a volatile and widely dispersed profit rate (Ariasih \& Mustanda, 2018), as well as the ideal security tool to make short-term investments by leveraging capital gains (Putra \& Dana, 2020). This reason lies on why investors who want instant profits must invest in stocks, particularly short-term investments since they can purchase shares and sell them back in a very short period to withdraw capital gains (Darmitha \& Purbawangsa, 2016).

\section{Method}

\subsection{Population and Sample}

Based on the problem studied, this study employed a quantitative approach. In this study, the population was all companies included in Liquid-45(LQ-45) index and listed in the Indonesia Stock Exchange (BEI) in 2019-2020. The companies as the samples were selected using a purposive sampling technique based on certain criteria. The inclusion criteria for selecting LQ-45 stock samples were those not subject to auto-reject more than 1 (one) time in 2019-2020.

\subsection{Data Collection Procedures}

The population were all companies included in the LQ45 index as shown in the Indonesia Stock Exchange from January 2019 to July 2020. Table 1 presents the list of the samples.

Table 1. Companies included in the LQ-45 index and listed on the IDX in 2019-2020

\begin{tabular}{lll}
\hline No & Code & Issuer Names \\
\hline 1 & ADRO & Adaro Energy Tbk. \\
2 & AKRA & AKR Corporindo Tbk. \\
3 & ANTM & Aneka Tambang Tbk. \\
4 & ASII & Astra Internasional Tbk. \\
5 & BBCA & Bank Central Asia Tbk. \\
6 & BBNI & Bank Negara Indonesia (Persero) Tbk. \\
7 & BBRI & Bank Rakyat Indonesia (Persero) Tbk. \\
8 & BBTN & Bank Tabungan Negara (Persero) Tbk. \\
9 & BMRI & Bank Mandiri (Persero) Tbk. \\
10 & BRPT & Barito Pacific Tbk. \\
11 & BSDE & Bumi Serpong Damai Tbk. \\
12 & CPIN & Charoen Pokphand Indonesia Tbk. \\
13 & ERAA & Erajaya Swasembada Tbk. \\
14 & EXCL & XL Axiata Tbk. \\
15 & GGRM & Gudang Garam Tbk. \\
16 & HMSP & H.M Sampoerna Tbk. \\
17 & ICBP & Indofood CBP Sukses Makmur Tbk. \\
18 & INCO & Vale Indonesia Tbk. \\
19 & INDF & Indofood Sukses Makmur Tbk
\end{tabular}




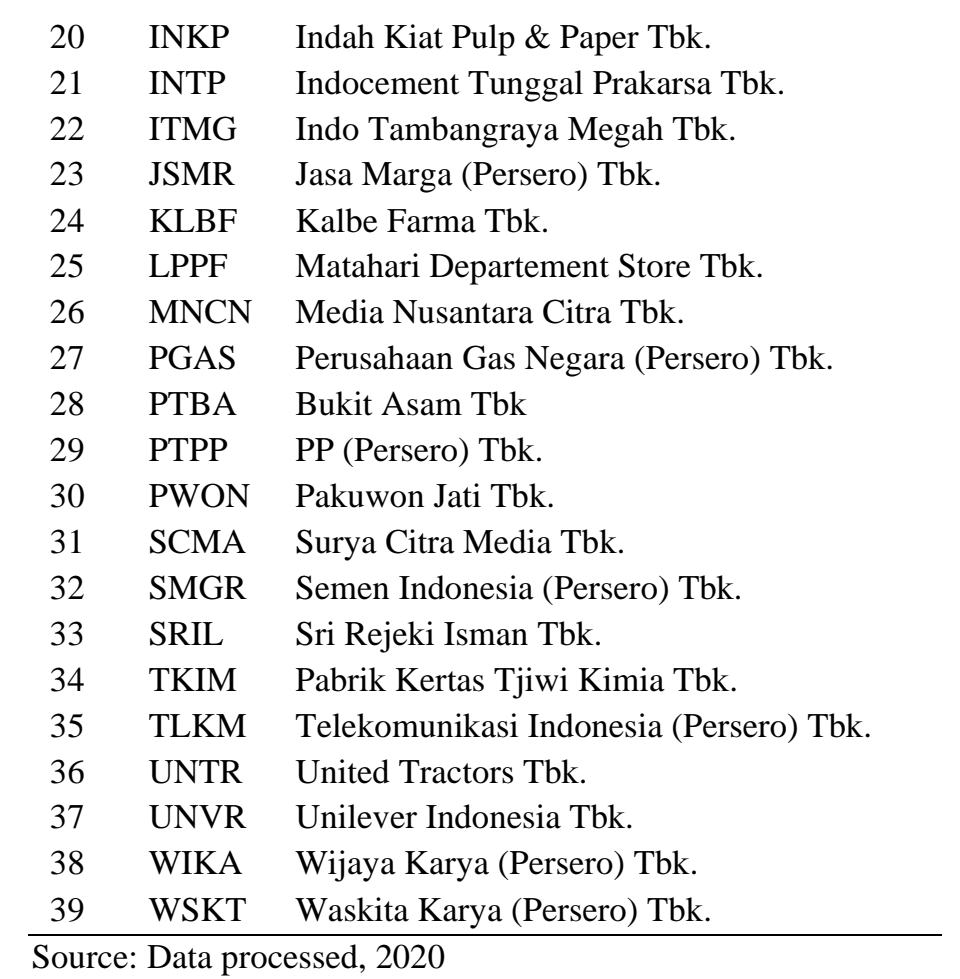

This study used non-observational data collection methods commonly known as observations made without involving oneself as an independent observer. Data were collected by accessing the website of Indonesia Stock Exchange on www.idx.co.id for shares in the LQ45 index and www.finance.yahoo.com for stock closing prices at the close of the month.

\subsection{Data Analysis}

The data analysis was performed by calculating through the application of Markowitz model which consists of the following steps.

1. Calculating the monthly stock return of each company.

Return from shares is the return received from investment shares in percentage units. The return from stock investment can be in the form of capital gain or loss. The stock return in this study was a reduction between the share price for now and the previous period. The return from shares can be calculated with the following equation (Hartono, 2014):

$$
R_{i t}=\frac{P_{i t}-P_{i(t-1)+D_{t}}}{P_{i(t-1)}}
$$

Which:

Rit $=$ Rate of return stock

$\mathrm{Pt}=$ Individual share price at the end of the period

Pt-1 = Individual share price at the beginning of the period

$\mathrm{Dt}=$ Share dividends received in shares $\mathrm{i}$

2. Calculating the expected return from shares of each company.

The expected return from shares is reflected future return as compared to previous return in percentage units. It was obtained from the average stock return in the companies listed in the LQ45 
index from January 2019 to July 2020. The expected rate of return can be calculated with the equation as follows (Hartono, 2014).

$$
\mathrm{E}\left(R_{i}\right)=\sum_{j=1}^{n} \frac{R_{i t}}{N}
$$

Which:

$\mathrm{E}(\mathrm{Ri})=$ The expected rate of return on stock $\mathrm{i}$

Rit $=$ Rate of return from shares $\mathrm{i}$ in period $\mathrm{i}$

$\mathrm{N}=$ Number of observation periods

3. Calculating the stock standard deviation of each sample firm that has a positive expected return.

Stock risk is a deviation from a return expected to be obtained, meaning that there is a difference between the expected return and the actual return. Share risk was calculated by using the standard deviation which measures the absolute value deviation from the value expected by the companies. The stock standard deviation was calculated using the following equation (Hartono, 2014).

$$
\sigma^{2}=\sqrt{\sum_{i=1}^{N} \frac{\left(R_{i t}-E\left(R_{i}\right)^{2}\right.}{N-1}}
$$

Which:

$\sigma^{2}=$ Stock risk

Rit0 $=$ Rate of return (return) stock $\mathrm{i}$ in period $\mathrm{t}$

$\mathrm{E}(\mathrm{Ri})=$ The expected rate of return on stock $\mathrm{i}$

$\mathrm{N}=$ Number of observation periods

4. Calculating covariance between stocks of each company

Covariance is a value indicating the extent of two variables; in this context, it is the return of both assets that tend to move simultaneously. Share covariance value was calculated using the following equation (Hartono, 2014).

$$
\sigma_{R i, R i}=\sum_{i, j=1}^{n} \frac{\left[\left(R_{i t}-E\left(R_{i}\right)\right) \cdot(R j t-E(R j))\right]}{n}
$$

Which:

$\sigma \mathrm{Ri}, \mathrm{Rj}=$ Return covariance between stock $\mathrm{i}$ and stock $\mathrm{j}$

Rit $=$ Stock return $\mathrm{i}$ in period $\mathrm{t}$

Rjt $=$ Return of stock $\mathrm{j}$ in period $\mathrm{t}$

$\mathrm{E}(\mathrm{Ri})=$ Expected return of stock $\mathrm{i}$

$E(R j)=$ Expected stock return $j$

$\mathrm{n}=$ Number of observation periods ([n] for the largest / most sample at least 30 observations and [n-1] for small samples) 
5. Calculating correlation coefficient between stocks of each company.

A correlation coefficient value indicates concurrent relative movements; in this study, it refers to the relationship of returns from one asset to another. Correlation coefficient value of each company was calculated using the following equation (Hartono, 2014).

$$
p x y=\frac{n \sum A B-\sum A \cdot \sum B}{\sqrt{\left[n \sum A^{2}-\left(\sum A\right)^{2}\right] \cdot\left[n \sum B^{2}-\left(\sum B\right)^{2}\right]}}
$$

Which:

$\rho_{A B}=$ Correlation coefficient between 2 stock returns

$\mathrm{n}=$ Number of observations

$A=$ Rate of return (return) from stock $A$

$\mathrm{B}=$ Rate of return (return) from stock B

6. Calculating expected return and portfolio risk at the same proportion

Expected return on the portfolio is the weighted average return of each stock that flows to the portfolio in percentage units. It was calculated by accumulating the product of the individual expected returns with the proportion of individual shares. Expected return portfolio of each company was calculated using the following equation (Hartono, 2014).

$$
\mathrm{E}(\mathrm{R} p)=\sum_{a=1}^{n} W i . E(R i)
$$

Which:

$\mathrm{E}(\mathrm{Rp})=$ Expected portfolio return

$\mathrm{E}(\mathrm{Ri})=$ Expected return of stock $\mathrm{i}$

$\mathrm{Wi}=$ Weight or portion of funds invested in stocks $\mathrm{i}$

$\mathrm{n}=$ Number of shares on the portfolio

Portfolio risk is the chance for investment failure in a portfolio in percentage units. Calculating portfolio risk needs to measure the standard deviation of each company. Difference was found since the portfolio had more than one stock. The other variable included was covariance, which measures the relationship of the movement of one share with other shares. The standard deviation of the portfolio was calculated using the following equation (Hartono, 2014).

$$
\sigma_{\rho}=\sqrt{\frac{X A^{2} \cdot \sigma A^{2}+X B^{2} \cdot \sigma B^{2}+2(X A \cdot X B . \rho A B \cdot \sigma A \sigma B)}{n}}
$$

Which:

$\sigma \rho 2=$ Portfolio variant

$\sigma \mathrm{p}=$ Risk of portfolio stocks

$\sigma \mathrm{A}, \sigma \mathrm{B}=$ Risk of shares $\mathrm{A}, \mathrm{B}$

$\rho \mathrm{AB}=$ Correlation coefficient for stocks $\mathrm{A}$ and $\mathrm{B}$

$\mathrm{XA}=$ Weight of funds invested in stock $\mathrm{A}$

$\mathrm{XB}=$ Weight of funds invested in stock $\mathrm{B}$

$\mathrm{n}=$ Number of observations

7. Calculating the optimal expected return and portfolio risk by minimizing the value of the variance and using the objective function. 
The seventh step was calculating the return value and standard optimal portfolio deviation which minimizes the variance with an objective function. After following the step correctly, the shares will be formed to be an optimal portfolio by looking for the proportion of optimal funds.

\section{Results}

The results of this study discussed the optimization of the stock portfolio listed in the LQ45 index in 2019-2020, as well as expected return and risk of the portfolio. The portfolio optimization process is presented at the following stages.

\subsection{Expected Return of Stock}

The expected return of stock was obtained after calculating the individual return of each stock. It is the level of profit expected by investors in the future (Tandelilin, 2010). The expected return of stock can be positive or negative. Stocks that have positive returns have a greater chance for being involved in an optimal portfolio. There were 11 issuers of the security with positive expected returns, namely ADRO, ANTM, BBCA, BRPT, ERAA, EXCL, INCO, JSMR, KLBF, MNCN, and WIKA.

Table 2. Expected Return of Each Stock

\begin{tabular}{clllll}
\hline No & Stock Code & E $(\mathrm{R})$ & No & Stock Code & E (R) \\
\hline 1 & ADRO & 0.0010 & 21 & INTP & -0.0176 \\
2 & AKRA & -0.0112 & 22 & ITMG & -0.0386 \\
3 & ANTM & 0.0085 & 23 & JSMR & 0.0091 \\
4 & ASII & -0.0184 & 24 & KLBF & 0.0049 \\
5 & BBCA & 0.0111 & 25 & LPPF & -0.0480 \\
6 & BBNI & -0.0233 & 26 & MNCN & 0.0237 \\
7 & BBRI & -0.0038 & 27 & PGAS & -0.0128 \\
8 & BBTN & -0.0152 & 28 & PTBA & -0.0350 \\
9 & BMRI & -0.0064 & 29 & PTPP & -0.0085 \\
10 & BRPT & 0.0677 & 30 & PWON & -0.0101 \\
11 & BSDE & -0.0246 & 31 & SCMA & -0.0100 \\
12 & CPIN & -0.0017 & 32 & SMGR & -0.0050 \\
13 & ERAA & 0.0071 & 33 & SRIL & -0.0241 \\
14 & EXCL & 0.0181 & 34 & TKIM & -0.0060 \\
15 & GGRM & -0.0224 & 35 & TLKM & -0.0094 \\
16 & HMSP & -0.0351 & 36 & UNTR & -0.0083 \\
17 & ICBP & -0.0041 & 37 & UNVR & -0.0016 \\
18 & INCO & 0.0123 & 38 & WIKA & 0.0011 \\
19 & INDF & -0.0046 & 39 & WSKT & -0.0318 \\
20 & INKP & -0.0044 & & & \\
\hline Source: & Processed data, 2020 & & &
\end{tabular}

\subsection{Stock Risk}

An investor does not certainly know the return obtained from an investment, while their goal is to maximize profits. However, in addition to returns, investors will also face investment risk. Investment risk refers to a condition when an investor fails to receive their capital back because the stock issuer is declared bankrupt or their stocks are not traded or have been removed from the listing on the Stock 
Exchange (Samsul, 2015). Investment risk can be interpreted as the difference between actual return and expected return. Risk and return are similar to currencies that always go side by side. One should not only calculate the expected return but also pay attention to the risks taken. Therefore, investors must be smart in looking for alternative investments that offer a certain return with the lowest risk level (Tandelilin, 2010). Stock risk proxy was determined by using the standard deviation of each stock. The stocks had a positive return. Stocks with a high standard deviation value had a high risk and the possibility of obtaining a high profit. Likewise, stocks with a low standard deviation value had a low risk and the possibility of obtaining a low profit. In Table 2, the highest standard deviation value was found in the stocks issued by Barito Pacific Tbk. at 0.2901, and the lowest one was found in the stocks issued by Bank Central Asia Tbk at 0.0549 .

\subsection{Covariance between Stocks}

Stock covariance indicates the simultaneous movement of two stock issuers. If the covariance of stocks shows a positive result, this indicates that the two issuers of the stocks are moving in the same direction. In other words, if the return from one stock increases, the return from other stocks will also increase and vice versa. Table 3 reveals that one of the positive results of the covariance between stocks was seen from the pair of ADRO and ANTM stocks at 0.0066, while the negative covariance was shown in the pair of ADRO and BRPT stocks at -0.0010 .

Table 3. Risk of Each Stock with a Positive Return

\begin{tabular}{|c|c|c|c|c|c|}
\hline No & $\begin{array}{l}\text { Stock } \\
\text { Code }\end{array}$ & Erit & $E(R)$ & $\begin{array}{c}\text { STDEV } \\
(\sigma)\end{array}$ & $\begin{array}{l}\text { VAR } \\
(\sigma 2)\end{array}$ \\
\hline 1 & ADRO & 0.0185 & 0.0010 & 0.1224 & 0.0142 \\
\hline 2 & ANTM & 1615 & 0.0085 & 0.1517 & 0.0218 \\
\hline 3 & $\mathrm{BBCA}$ & 0.2105 & 0.0111 & 0.0549 & 0.0029 \\
\hline 4 & BRPT & 1.2864 & 0.0677 & 0.2901 & 0.0797 \\
\hline 5 & ERAA & & 0.0071 & 0.2502 & 0.0593 \\
\hline 6 & EXCL & 0.3430 & 0.0181 & 0.1096 & 0.0114 \\
\hline 7 & INCO & 0.23 & 0.0123 & 0.1441 & 0.0197 \\
\hline 8 & JSMR & 0.1729 & 0.0091 & 0.1553 & 0.0229 \\
\hline 9 & KLBF & & & 0.0849 & 0.0068 \\
\hline 10 & MNCN & 0.4496 & 0.0237 & 0.1768 & 0.0296 \\
\hline 11 & WIKA & 0.0204 & 0.0011 & 0.1684 & 0.0269 \\
\hline
\end{tabular}

Source: Processed data (2020)

\subsection{Expected Return and Risk of Portfolios with Equal Weight}

A portfolio that is formed using an equal weight can be compared to a portfolio with an optimal weight. The first step was to calculate the proportion of the portfolio weight by dividing $100 \%$ by the number of stocks in 11 stocks. It was found the same amount of weight per stock at $0.0909 \%$ or $9.09 \%$. Table 4 presents that a portfolio consisting of 11 stocks with a $9.09 \%$ weight each produced an expected return of $1.50 \%$ and a standard deviation of $10.52 \%$. 
Table 4. Expected Return and Risk of Portfolios with Equal Weight

\begin{tabular}{cccc}
\hline No & Stock Code & Weight & E (R) \\
\hline 1 & ADRO & $9.09 \%$ & 0.0010 \\
2 & ANTM & $9.09 \%$ & 0.0085 \\
3 & BBCA & $9.09 \%$ & 0.0111 \\
4 & BRPT & $9.09 \%$ & 0.0677 \\
5 & ERAA & $9.09 \%$ & 0.0071 \\
6 & EXCL & $9.09 \%$ & 0.0181 \\
7 & INCO & $9.09 \%$ & 0.0123 \\
8 & JSMR & $9.09 \%$ & 0.0091 \\
9 & KLBF & $9.09 \%$ & 0.0049 \\
10 & MNCN & $9.09 \%$ & 0.0237 \\
11 & WIKA & $9.09 \%$ & 0.0011 \\
\multicolumn{4}{c}{ TOTAL } \\
Expected Return of Portfolio & $1.50 \%$ \\
Deviation Standard of Portfolio & $10.52 \%$ \\
\hline
\end{tabular}

Source: Processed data, 2020

\subsection{Expected Return and Risk of Portfolio with Optimal Weight}

A portfolio with an optimal weight was compared with those which weight was equal. The optimal weight portfolio was calculated using a solver program in the Microsoft Excel application. This program was applied to find out the proportion of stocks which can produce an optimal portfolio by minimizing its risk. The calculation results showed that the optimal portfolio consisted of 2 stock issuers, namely BBCA with a weight of $78.09 \%$ and BRPT with a weight of $21.91 \%$. In Table 5, the portfolio with an optimal weight produced an expected return of $2.35 \%$ and a standard deviation of $7.01 \%$.

Table 5. Expected Return and Risk of Portfolio with Optimal Weight

\begin{tabular}{ccrc}
\hline No & Stock Code & Weight & E (R) \\
\hline 1 & BBCA & $78.09 \%$ & 0.0111 \\
2 & BRPT & $21.91 \%$ & 0.0677 \\
\multicolumn{4}{c}{$100.00 \%$} \\
\multicolumn{4}{c}{ Expected Return of Portfolio } \\
\multicolumn{2}{c}{ Deviation Standard of Portfolio } & $2.35 \%$ \\
\hline
\end{tabular}

Source: Processed data, 2020 


\section{Discussion}

From the data analysis and calculations, there were evident differences in the number of stock issuers that made up a portfolio. The first calculation using the same weight showed that a portfolio consisting of 11 stocks with a weight of $9.09 \%$ each produced an expected return value of $1.50 \%$ and a standard deviation of $10.52 \%$. Meanwhile, the second calculation which used the optimal weight resulted in the portfolio consisting of 2 stock issuers, namely BBCA with a weight of $78.09 \%$ and BRPT with a weight of $21.91 \%$. This calculation produced an expected return value of $2.35 \%$ and a standard deviation of $7.01 \%$. BBCA stocks had the highest proportion or weight of funds at $78.09 \%$ due to having the lowest standard deviation or risk among the other 11 stock issuers. However, although BBCA stocks showed the lowest risk, it did not guarantee investors to get a big return from the investment. The fact was the expected return from BBCA was not greater than the expected return of the portfolio. The second issuer in the optimal portfolio was BRPT with a weight of $21.91 \%$ since they had the highest expected return value among other stock issuers and had a negative covariance with BBCA. Negative covariance values can reduce the risk of the portfolio. Even though BRPT stocks had the highest expected return value, investors were not advised to invest all their funds in the stocks due to their considerable risk.

The difference in calculating the portfolios either with the equal weight or the optimal weight can be seen from the values of the expected return and standard deviation. A portfolio with the same weight produced an expected return of $1.50 \%$, while that with an optimal weight produced an expected return of $2.35 \%$. The results showed the expected return received by investors increased by $0.85 \%$, while the standard deviation for a portfolio with the same weight showed $10.52 \%$. Further, the standard deviation for a portfolio with an optimal weight resulted in a value of $7.01 \%$. The standard deviation or risk resulted from the investment decreased by $3.51 \%$. This confirmed that the formation of a portfolio with an optimal weight using the Markowitz model provided a higher value of expected return with a lower level of risk. In addition, the results also illustrated that the diversification following the Markowitz model evidently could provide an optimal portfolio with a minimum risk compared to the investment made in one stock issuer. The optimal portfolio formed using the Markowitz model is very suitable to be applied to risk-averse investors or those who do not like a high risk but desire optimal returns.

\section{Conclusions}

Based on the results described previously, it can be concluded that the optimal portfolio formation using the Markowitz model was observed from 2 stocks, namely BBCA and BRPT stocks. The proportions of the two stocks were $78.09 \%$ and $21.91 \%$ for BBCA and BRPT, respectively. Evaluation of optimal portfolio using the Markowitz parameters showed that the highest expected return and lowest risk was at $2.35 \%$ and $7.01 \%$, respectively. This study also illustrated that the diversification based on the Markowitz model could pose an optimal portfolio with a minimum risk compared to investments made in one stock issuer. An optimal portfolio formed using the Markowitz method is proper for riskaverse investors, who do not like a high risk but desire optimal returns. 


\section{Acknowledgments}

Our gratitude goes to the Directorate of Research and Community Service, University of Muhammadiyah Sidoarjo (DRPM Umsida) for provide funds through the Institutional Applied Research Program scheme.

\section{References}

Agus, I. K., Swara, A., \& Dana, I. (2020). Study of Optimal Portfolio Performance Comparison : Single Index Model and Markowitz Model on LQ45 Stocks in Indonesia Stock Exchange. American Journal of Humanities and Social Sciences Research (AJHSSR), 237-244.

Ariasih, N. L., \& Mustanda, I. K. (2018). Pembentukan Portofolio Optimal Menggunakan Model Indeks Tunggal Pada Saham Indeks Lq 45. E-Jurnal Manajemen, 4508 - 4538. https://doi.org/10.24843/EJMUNUD.2018.v07.i08.p17

Darmadji, T., \& Fakhruddin, H. M. (2012). Pasar Modal di Indonesia: Pendekatan Tanya Jawab. Jakarta: Salemba Empat.

Darmitha, S., \& Purbawangsa, I. B. (2016). Study komparatif kinerja portofolio optimal saham lq-45 dan 50 most active stocks by trading frequency. E-jurnal Manajemen. https://ojs.unud.ac.id/index.php/Manajemen/article/view/24473

Dewi, C., \& Masithoh, R. (2020). JKSE and trading activities before after Covid-19 outbreak. Research Journal of Accounting and Business Management, 1-6.

Elton, E. J., Gruber, M. J., Brown, S. J., \& Goetzmann, W. N. (2014). Modern Portfolio Theory and Investment Analysis. New York: Wiley.

Gurrib, I. (2014). Diversification in Portfolio Risk Management: The Case of UAE Financial Market. International Journal of Trade, Economic and Finance, 445-449.

Halim, A. (2015). Analisis Investasi dan Aplikasinya: dalam Aset Keuangan. Jakarta: Salemba Empat. Hartono, J. (2014). Teori Portofolio dan Analisis Investasi. Yogyakarta: BPFE.

Husnan, S. (2009). Dasar-Dasar Teori Portofolio dan Analisis Sekuritas. Yogyakarta: Sekolah Tinggi Ilmu Manajemen YKPN.

Natalia, E. (2014). Penentuan Portofolio Saham yang Optimal dengan Model Mrkowitz sebagai Dasar Penetapan Investasi Saham (Studi pada Perusahaan Food and Beverage yang Terdaftar di Bursa Efek Indonesia Tahun 2012). Jurnal Administrasi Bisnis, 9.

Pratama, A., Purba, K., Jamhur, J., \& Prasetyo, P. (2020). Pengaruh Faktor Perilaku Investor Saham terhadap Keputusan Investasi di Bursa Efek Indonesia. Jurnal Akuntansi dan Keuangan, 170179.

Putra, I. K., \& Dana, I. M. (2020). Study of Optimal Portfolio Performance Comparison: Single Index Model and Markowitz Model on LQ45 Stocks in Indonesia Stock Exchange. American Journal of Humanities and Social Sciences Research (AJHSSR), 237-244. https://doi.org/10.18502/kss.v4i3.6410

Qing , H., Junyi , L., Sizhu , W., \& Jishuang, Y. (2020). The impact of COVID-19 on stock markets. Economic and Political Studies, 275-288. doi:10.1080/20954816.2020.1757570

Samsul, M. (2015). Pasar Modal dan Management Portofolio. Surabaya: Erlangga.

Sunariyah. (2006). Pengantar Pengetahuan Pasar Modal. Yogyakarta: UPP AMP YKPN.

Tandelilin, E. (2010). Portofolio dan Investasi: Teroti dan Aplikasi. Edisi Pertama. Yogyakarta: Kanisius.

Ticoh, J. (2010). Optimalisasi Portofolio Proyek Dengan Menggunakan Kurva Efisien Markowitz. Jurnal Pendidikan Teknologi dan Kejuruan, 204-215. 
Wiryakusuma, I. G. (2020). Analysis of Optimal Portfolio Performance Comparison on Companies Listed in LQ45 Index and Companies Unregistered in LQ45 Index. KnE Social Sciences, 250261. https://doi.org/10.18502/kss.v4i3.6410

Zalmi, Z. (2011). Manajemen Portofolio: Penerapannya dalam Investasi. Jakarta: Salemba Empat. 
Optimalisasi Portofolio Saham Menggunakan Model Markowitz di Era Pandemi COVID-19

\begin{abstract}
Abstrak
Saham merupakan salah satu instrumen investasi populer yang diperdagangkan di pasar modal. Popularitas saham berkembang seiring dengan masifnya gerakan literasi keuangan untuk membeli saham. Namun masifnya pergerakan ini harus diimbangi dengan pengetahuan dan keahlian dalam mengelola instrumen saham, karena saham merupakan instrumen investasi dengan tingkat pengembalian yang tinggi dan risiko yang tinggi. Salah satu cara untuk mengelola saham adalah dengan mengembangkan portofolio saham yang optimal berdasarkan Model Markowitz. Metode Markowitz Model merupakan metode yang merumuskan adanya elemen return dan risiko dalam suatu investasi, dimana elemen risiko dapat diminimalisir melalui diversifikasi dan penggabungan berbagai instrumen investasi ke dalam suatu portofolio. Dengan menggunakan metode Markowitz, investor dapat memanfaatkan semua informasi yang tersedia sebagai dasar pembentukan portofolio yang maksimal. Penelitian ini bertujuan untuk mengetahui saham mana yang dapat membentuk portofolio optimal khususnya di era pandemi COVID 19 dan untuk mengetahui proporsi portofolio optimal dari masing-masing saham yang layak untuk memperoleh portofolio optimal pada saham yang terdaftar di Indeks LQ 45. Sampel penelitian melibatkan saham yang terdaftar di Indeks LQ 45. Teknik analisis data yang digunakan dalam penelitian ini adalah optimasi portofolio dengan menggunakan Model Markowitz. Hasil penelitian menunjukkan bahwa portofolio optimal terdiri dari BBCA dengan bobot $78.09 \%$ dan BRPT dengan bobot $21.91 \%$ yang menghasilkan expected return sebesar $2,35 \%$ dan standar deviasi $7,01 \%$.
\end{abstract}

Kata kunci: Optimasi; portofolio; saham; model Markowitz 